\title{
STUDY ON PLANT GROWTH PROMOTER FROM PROTEINEOUS WASTES FROM LEATHER INDUSTRY
}

\author{
Victor JOHN SUNDAR*, Govindaswamy RAMAMURTHY, Thotapalli Parvathaleswara SASTRY
}

CSIR-Central Leather Research Institute, Adyar, Chennai - 600020, Tamil Nadu, India, e-mail: johnsundar70@yahoo.co.uk

Received: 11.01.2017

Accepted: 28.04.2017

https://doi.org/10.24264/Ifj.17.2.2

STUDY ON PLANT GROWTH PROMOTER FROM PROTEINEOUS WASTES FROM LEATHER INDUSTRY

ABSTRACT. Tanneries generate huge quantities of solid wastes as fleshings. If these bio-waste materials are not utilized properly they are potential source of pollution. So in the present study it has been tried to convert these hide fleshings into NPK fertilizer. During the process of manufacture of NPK fertilizer, phosphorous and potassium were incorporated by suitable chemical reaction under desired conditions of temperature and pressure. The resultant liquid product was converted into pellet form and field tested on horticulture plants (Balsam Plant - Impatiens balsamina).

KEY WORDS: animal fleshings, fertilizers, nitrogen, phosphorus, potassium.

\section{STUDIU ASUPRA UNUI FERTILIZATOR PENTRU CREŞTEREA PLANTELOR DIN DEŞEURI PROTEICE DIN INDUSTRIA DE PIELĂRIE}

REZUMAT. Tăbăcăriile generează cantităţi uriaşe de deşeuri solide sub formă de şeruitură. Dacă aceste deşeuri organice nu sunt utilizate în mod corespunzător, devin o sursă potenţială de poluare. Aşadar, în studiul de faţă s-a încercat transformarea acestei şeruituri în fertilizator NPK. La fabricarea fertilizatorului NPK, s-au încorporat fosfor și potasiu prin reacție chimică corespunzătoare în condițiile dorite de temperatură şi presiune. Produsul lichid obţinut a fost prelucrat sub formă de granule şi s-a testat pe plante horticole (balsamină - Impatiens balsamina). CUVINTE CHEIE: şeruitură de origine animală, fertilizator, azot, fosfor, potasiu.

\section{ÉTUDE SUR UN ENGRAIS POUR LA CROISSANCE DES PLANTES À PARTIR DE DÉCHETS PROTÉINES DE L'INDUSTRIE DE CUIR}

RÉSUMÉ. Les tanneries génèrent énormes quantités de déchets solides en tant que déchets d'écharnage. Si ces déchets organiques ne sont pas utilisés correctement, ils sont une source potentielle de pollution. Ainsi, dans la présente étude, on a essayé de convertir ces déchets d'écharnage en engrais NPK. Au cours de la fabrication de l'engrais NPK, le phosphore et le potassium ont été incorporés par une réaction chimique appropriée dans les conditions souhaitées de température et de pression. Le produit liquide résultant a été converti en forme de pastille et testé sur des plantes horticoles (la balsamine - Impatiens balsamina).

MOTS CLÉS: déchets d'écharnage, engrais, azote, phosphore, potassium.

\section{INTRODUCTION}

The generation of large quantum of tannery wastes is an environmental threat and their nonutilization or non-treatment would result in health hazards $[1,2]$. So in this research work it has been ventured to utilize these solid wastes to produce a value added product viz., NPK fertilizer. Nitrogen $(\mathrm{N})$ phosphorous $(\mathrm{P})$ and potassium (K) are the most important macronutrients required for growth and development of plants. Earlier literature dealt with meat and bone meal (MBM) that contained appreciable amounts of total nitrogen, phosphorous and calcium which were applied as fertilizer for various crops.

In two experiments with spring wheat increased amount of MBM showed linear yield increase related to the $\mathrm{N}$ supply. A similar experiment on barley gave positive yield increase for $500 \mathrm{MBM} \mathrm{ha}^{-1}$ and no further increase for large amounts of MBM [3]. In another report a screen house study was conducted to evaluate the effect of compound fertilizer (NPK) on the response of cassava (Manihot esculenta Crantz) to diseases, pests and mycorrhizal symbiosis. NPK was applied to the soil drenches. Mycorrhizal spores in rhizopore soil and root colonization of cassava by arbuscular mycorrhizal (AM) fungi were estimated after 5.5 months. Incidents of pests-cassava green spider mites (CGM) cassava meelybug (CM), African cassava moossaic disease (ACMD) and cercospora leaf spot disease (CLSD) were rated on varying scales. In this experiment it was found that the mycorrhizal spores and colonization were significantly higher in control experiments. NPK fertilizer significantly increased plant vigour (stem \& girth) and also diminished the occurrences of CGM, CM and ACMD [4]. In another report a pot experiment was conducted in the wire house to compare the effects of two precursors (calcium carbide and L-methionine) of ethylene on growth and yield of tomato. This experiment showed that the tomato plants grown in combination with NPK

\footnotetext{
* Correspondence to: Victor JOHN SUNDAR, Leather Process Technology Division, CSIR-Central Leather Research Institute, Adyar, Chennai 600020, Tamil Nadu, India, e-mail: johnsundar70@yahoo.co.uk
} 
fertilizer gave good results in terms of number of flowers per plant, number of fruits per plant, shoot dry weight, fruit dry weight, root dry weight, nitrogen in shoot (\%) and nitrogen in fruit (\%) [5]. In another report a long term experiment was conducted on Aquic Hapludoll under rice-wheat-cowpea system. It was realized that treatment given with $100 \%$ NPK + farmyard manure and $100 \%$ NPK fertilizer $+\mathrm{Zn}$ gave better results than other treatments [6]. In one more report, the effect of NPK fertilizer on growth and yield of banana has been investigated. The result of the study indicated that vegetative growth parameters (i.e., leaf number, leaf area, stem height and stem circumference) of non-fertilized control plants were neither significantly different nor produced better vegetative growth when compared to NPK fertilized plants [7]. In recent times, protein hydrolysate derived from leather wastes had also been used as biostimulant to activate plant growth thereby increasing the yield of the crops has been reported [8].

In this paper a new process for preparation and application of NPK fertilizer from bio-wastes i.e., tannery fleshings has been reported. In the present investigation phosphorous and potassium were incorporated under suitable experimental conditions with the animal fleshings which are rich source of nitrogen. The obtained NPK product was field tested in horticultural plant (Balsam - Impatiens balsamina) and found to give good results in terms of size of the plant, size of the leaf area and dry weight of the plant.

\section{MATERIALS AND METHODS}

\section{Preparation of NPK Fertilizer}

The process of hydrolysis of animal fleshings with strong acids such as hydrochloric acids and sulphuric acid and pancreatic enzymes are already established [9]. In the present work, orthophosphoric acid is used to incorporate phosphorous in the product. $2 \mathrm{Kg}$ of hide fleshings was taken (which was previously washed thoroughly) in the oil sealed high pressure autoclave. 6\% orthophosphoric acid $(\mathrm{w} / \mathrm{v})$ was added along with 1 liter of water and hydrolyzed in the pressure of 50 Psi for 3 hours. After complete digestion the solution was filtered and the fat content which is settled on the top was removed using a separating funnel. The liquor collected was neutralized to $\mathrm{pH} 7.0$ using 50\% Potassium hydroxide solution (V/W) and was concentrated at $80^{\circ} \mathrm{C}$ for 8 to 10 hours.

The concentrated NPK solution was mixed with known quantity of inert materials like china clay or leaf mould and the mixture was semi dried and converted into pellets for further field experimentation. The obtained NPK pellets are analysed and used for application studies.

\section{RESULTS AND DISCUSSION}

\section{Characterization of NPK Solution}

According to the official procedure [10-13] the total nitrogen, phosphorus and potassium was estimated for the obtained NPK product and is shown in Table 1.

Table 1: Estimation of macronutrients

\begin{tabular}{ccc}
\hline S.No & Macro Nutrients & Quantity \\
\hline 1 & Nitrogen as N & $1.02 \pm 0.01 \%$ \\
2 & Phosphorous as P & $2.38 \pm 0.02 \%$ \\
3 & Potassium as K & $2.21 \pm 0.02 \%$ \\
\hline
\end{tabular}

\section{Infrared Spectroscopy Study of NPK Product}

The obtained NPK pellet was analyzed for its nitrogen quantity. The analysis of FTIR spectroscopy reveals the relevant amount of compositional and structural information concerning the subjected sample. The IR spectrum of the sample was taken using Nicolet Impact spectroscopy by preparing a $500 \mathrm{mg} \mathrm{KBr}$ pellet containing 2-6 mgs of the sample.

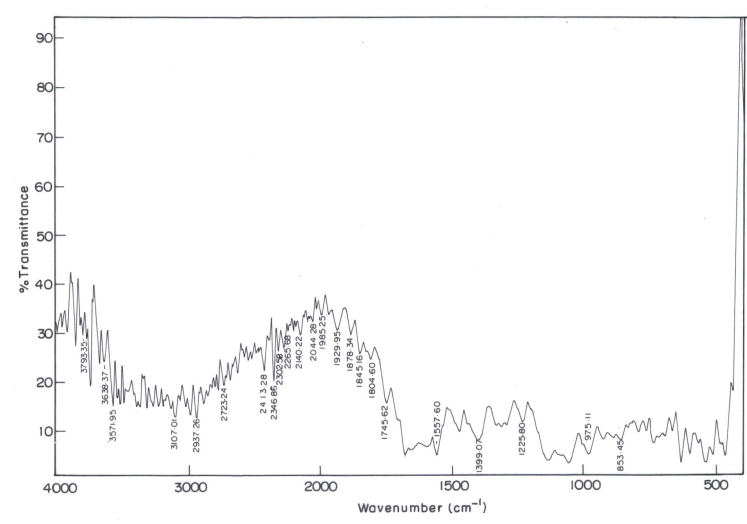

Figure 1. IR spectrum of NPK fertilizer 
The IR spectrum of the sample analysed shows the characteristic peaks of collagen. The amide I absorption bands are seen at $1655 \mathrm{~cm}^{-1}$ and this band leads to the stretching vibration of the $\mathrm{C}=\mathrm{O}$ bond of amide group. Amide II absorption bands are seen at $1557 \mathrm{~cm}^{-1}$ which leads primarily to bending vibration of the $\mathrm{N}-$ $\mathrm{H}$ bond [14].

Apart from the above important functional groups of amino acids Aspargin and Glutamin of skin protein, other groups are also seen [15]. Thiocyanate group (SCN) at absorption band of $2140 \mathrm{~cm}^{-1}$ amide $\mathrm{B}$ (NH stretching) band is seen at $3107 \mathrm{~cm}^{-1}$. Carboxylic acid group is seen at absorption band of $2937 \mathrm{~cm}^{-1}$. Amines are noticed at $1225 \mathrm{~cm}^{-1}$. Hydroxy group $(\mathrm{H}$ bonded $\mathrm{OH}$ stretch) are seen at $3571 \mathrm{~cm}^{-1}$. The above spectral data confirms the presence of nitrogen in the NPK fertilizer taken for study.

\section{Application of NPK Fertilizer}

A different level of standard fertilizers were taken in two batched at the rate of 3 pots per batch. In first batch all the three pots were given red soil, river soil and farmyard manure were taken in 1:1:1 ratio respectively out of which the first two pots were given $100 \mathrm{~g}$ of NPK fertilizer each. These two pots were experiment I and experiment II of batch1 and the third pot was control without NPK fertilizer. In the second batch all the 3 pots were taken with red soil, river soil and farmyard manure in the ratio of 1:1:2. Here also the first two pots were given $200 \mathrm{~g}$ of NPK fertilizer. These two pots were experiment I and experiment II of second batch. The third pot was without NPK fertilizer and it served as control for second batch.



Figure 2. Experiment plants - Balsam Plant

The plants and soil were irrigated with equal quantity of fresh water as and when required. Plants were monitored for the growth for 20 days to assess the efficacy of the NPK fertilizer on plants. The balsam plants were raised in earthen pots lined with sand at the bottom and filled with $4 \mathrm{~kg}$ of different proportions of soils as shown in the Table 2 .

Table 2: Application experiments on plants

\begin{tabular}{|c|c|c|c|c|c|}
\hline Components & Composition & NPK Fertilizer & Pot No. & Batch & Experiments \\
\hline Red soil & & $100 \mathrm{~g}$ & 1 & & Experiment I \\
\hline River soil & 1:1:1 & $100 \mathrm{~g}$ & 2 & Batch 1 & Experiment II \\
\hline Farmyard manure & & $0^{\circ}$ & 3 & & Control \\
\hline Red soil & & $200 \mathrm{~g}$ & 4 & & Experiment I \\
\hline River soil & $1: 1: 2$ & $200 \mathrm{~g}$ & 5 & Batch 2 & Experiment II \\
\hline Farmyard manure & & 0 & 6 & & Control \\
\hline
\end{tabular}

\section{Analysis of Plant Products}

In Table 3, though the percentage of dry weight of all the plants of batch 1 and batch 2 seem to uniformly equal, the weight of fresh plants of batch 2 are higher. This is again an indication of the effect of NPK fertilization and manure ratio stated in batch 2 .

Table 3: Fresh and dry weights of the plants

\begin{tabular}{|c|c|c|c|c|c|c|}
\hline S.No & Description & $\begin{array}{l}\text { Soil \& Manure } \\
\text { ratio }\end{array}$ & NPK & $\begin{array}{l}\text { Weight of the } \\
\text { fresh plants }\end{array}$ & $\begin{array}{l}\text { Weight of the dry } \\
\text { plants }\end{array}$ & $\begin{array}{c}\text { Dry weight of plants } \\
(\%)\end{array}$ \\
\hline 1 & & & $100 \mathrm{~g}$ & $104.0 \mathrm{~g}$ & $15.0 \mathrm{~g}$ & 14.4 \\
\hline 2 & Batch 1 & 1:1:1 & $100 \mathrm{~g}$ & $120.0 \mathrm{~g}$ & $17.0 \mathrm{~g}$ & 14.2 \\
\hline 3 & & & 0 & $84.0 \mathrm{~g}$ & $12.4 \mathrm{~g}$ & 14.8 \\
\hline 4 & & & $200 \mathrm{~g}$ & $141.0 \mathrm{~g}$ & $20.0 \mathrm{~g}$ & 14.2 \\
\hline 5 & Batch 2 & $1: 1: 2$ & $200 \mathrm{~g}$ & $158.0 \mathrm{~g}$ & $22.7 \mathrm{~g}$ & 14.4 \\
\hline 6 & & & 0 & $102.0 \mathrm{~g}$ & $15.3 \mathrm{~g}$ & 15.0 \\
\hline
\end{tabular}


The plants were grown for 20 days in normal condition. From the above experiments it was found that the plants grown in the level of 1:1:2 and NPK fertilizer 200 g gave good result. The plants were bigger with thicker stems and dark green leaves. The dry weights of the plants were also higher compared to control plants.

\section{CONCLUSION}

Bio wastes such as skin and hide fleshings are generated in the tanneries in large quantities during processing all over the world. In the event of non utilization of these materials they may cause environmental pollution. So the present work has been ventured into utilize the waste materials into value added products namely NPK fertilizer. Presently this product has been applied on horticulture plant i.e., Balsam Plant. It has been planned to apply the NPK product in during the cultivation of paddy, corn etc. By this kind of application in the field, it is possible to reduce the commercial synthetic fertilizers.

\section{REFERENCES}

1. Kanagaraj, J., Velappan K.C., Chandrababu, N.K, Sadulla, S., Solid Wastes Generation in the Leather Industry and its Utilization for Cleaner Environment - A Review, I Sci Ind Res, 2006, 65, 541-548, https://doi.org/10.1002/ chin. 200649273.

2. Ramasamy, T., From Ore to Brick: Travel of Chromium through the Cross Roads of Indian Leather Sector, Workshop on Building Ceramic from Industrial Wastes (International Centre for Science and Technology \& UNIDO, Trivandrum), 1999, 132-149.

3. Jeng, A.S., Haraldsen, T.K., Gronlund, A., Pederson, P.A., Meat and Bone Meal as Nitrogen and Phosphorus Fertilizer to Cereals and Rye Grass, Nutr Cycl Agroecosyst, 2006, 76, 183-191, https://doi.org/10.1007/ s10705-005-5170-y.

4. Omorusi, V.I., Ayanru, D.K.G., Effect of NPK Fertilizer on Diseases, Pests and Mycorrhizal Symbiosis in Cassava, Int J Agric Biol, 2011, 13, 391-395.

5. Siddiq, S., Yaseen, M., Meldi, S.A.R., Khalid, A., Kashif, S.R., Growth and Yield Response of Tomato to Soil Applied Calcium Carbide and L methionine, Pak J Bot, 2009, 41, 2455-2464.
6. Ram, N., Long Term Effect of Fertilizers on Rice-Wheat-Cowpea Productivity and Soil Properties in a Mollisols, Rice - Wheat Consortium for the Indo-Gangetic Plains: An Ecoreginal Partnership in South Asia, 2012, 50-55.

7. Harthi, K., Yahyai, R., Effect of NPK Fertilizer on Growth and Yield of Banana in Northern Oman, J Hort Forest, 2009, 1, 8, 160-167.

8. Adejumo, T.O., Effect of NPK Fertilization on Yield and Inflorescence Blight of Cashew (Anacardium occidentale), J Agric Biotech Sustain Dev, 2010, 2, 5, 66-70.

9. Pecha, J., Furst, T., Kolomaznik, K., Friebrova, V., Svoboda, P., Protein Biostimulant Foliar Uptake Modeling: The Impact of Climatic Conditions, AlChE J, 2012, 58, 7, 2010-2019, https://doi.org/10.1002/aic.12739.

10. Kumaraguru, S., Sastry, T.P., Rose, C., Hydrolysis of Tannery Fleshings Using Pancreatic Enzymes: A Biological Tool for Waste Management, Am Leather Chem Assoc, 1998, 93, 32-38.

11. Subbiah, B.V., Asija, G.L., A Rapid Method for Estimation of Available Nitrogen in Soils, Curr Sci, 1956, 25, 8, 259-260.

12. Anja, G., Ewald S., Leila, H., A Contribution to the Estimation of Organic Phosphorous in Soils, International Symposium on Soil and Plant Analysis, Cape Town, South Africa, 2005, 36, 1-3, 355-361.

13. Temperli, A.T., Misteli, H., Determination of Potassium in Soil Extracts by Atomic Absorption Spectrometry, Federal Research Station of Biochemistry, Anal Biochem, 1969, 27, 2, 361-363.

14. Krimm, S., Bandekar, J., Vibrational Spectroscopy and Conformation of Peptides, Polypeptides and Proteins, Adv Protein Chem, 1986, 38, 181-364.

15. Hanway, J.J., Heidal, H., Soil Analysis Methods as Used in lowa State College, Soil Testing Laboratory, lowa State College Bull, 1952, 57, 1-131.

(C) 2017 by the author(s). Published by INCDTPICPI, Bucharest, RO. This is an open access article distributed under the terms and conditions of the Creative Commons Attribution license (http://creativecommons.org/licenses/by/4.0/). 